\title{
Analisis Kesalahan Siswa dalam Mengerjakan Soal Pada Materi Trigonometri Ditinjau dari Strategi Kuis
}

\author{
${ }^{1}$ Gusti Ayu Mahayukti, ${ }^{2}$ Made Juniantari \\ Prodi S1 Pendidikan Matematika FMIPA Undiksha, Indonesia
}

Email: ${ }^{1}$ gustiayumahayukti@undiksha.ac.id, ${ }^{2}$ mdjuniantari@undiksha.ac.id

\begin{tabular}{l}
\hline Tersedia Online di \\
\hline http://www.jurnal.unublitar.ac.id/ \\
index.php/briliant \\
\hline Sejarah Artikel \\
\hline Diterima pada 23 Juli 2020 \\
Disetujui pada 28 Oktober 2020 \\
Dipublikasikan pada 30 \\
November 2020 \\
Hal. 687-697 \\
\hline \\
\hline Kata Kunci: \\
\hline Kahoot; WhatsApp; Kuis; \\
Trigonometri \\
DOI: \\
\hline http://dx.doi.org/10.28926/briliant \\
v3i4.523
\end{tabular}

\begin{abstract}
Abstrak: Penelitian ini bertujuan untuk mengidentifikasi kesalahan yang dilakukan siswa dalam menyelesaikan soal Trigonometri ditinjau dari strategi kuis yang digunakan dan untuk mengidentifikasi faktor-faktor penyebab kesalahan siswa dalam mengerjakan soal. Subjek penelitian adalah siswa kelas X MIPA 4 dan kelas X MIPA 5 SMA Negeri 1 Negara. Dalam penelitian ini, strategi kuis yang digunakan untuk siswa MIPA 5 adalah melalui media Kahoot sedangkan siswa kelas MIPA 5 melalui media WhatsApp. Data dikumpulkan dengan teknik tes uraian dan teknik wawancara. Hasil analisis data menunjukkan persentase kesalahan konsep, prosedur dan komputasi yang dilakukan oleh siswa kelas X MIPA 4 lebih rendah daripada siswa kelas X MIPA 5. Hal ini berarti strategi kuis yang digunakan merupakan salah satu faktor penyebab kesalahan siswa dalam mengerjakan soal.
\end{abstract}

\section{PENDAHULUAN}

Matematika merupakan mata pelajaran yang mampu mengarahkan siswa untuk berpikir secara logis, sistematis cermat efektif dan efisien (Suherman, dkk, 2003). Namun pada kenyataannya, prestasi belajar matematika siswa masih rendah. Hal ini dibuktikan berdasarkan hasil kuis, ulangan harian, ujian akhir semester, dan bahkan pada ujian nasional pada mata pelajaran matematika masih rendah. Berdasaran hasil observasi yang penulis lakukan melalui pemberian kuis pada materi Trigonometri bagi siswa kelas $\mathrm{X}$ MIPA 4 dan siswa kelas X MIPA 5 SMA Negeri 1 Negara, diperoleh gambaran bahwa terjadi berbagai bentuk kesalahan siswa dalam mengerjakan soal yang mencerminkan rendahnya kemampuan matematika siswa.

Menurut Nurfauziah \& Sari (2018) Trigonometri merupakan konsep yang sukar untuk dipahami. Hal ini sejalan dengan pendapat Hayati (2019) yang menyatakan bahwa salah satu materi pada mata pelajaran Matematika yang dirasa sulit oleh siswa adalah Trigonometri. Nurfauziah \& Sari (2018) dan Hayati (2018) sejalan dengan pendapat Cooney \& Cotton (dalam Khiat, 2010: 1461) mengungkapkan bahwa terdapat perbedaan pandangan siswa terhadap matematika, yang satu pihak melihat matematika sebagai sesuatu yang menarik dan pihak lainnya melihat matematika sebagai sesuatu yang membosankan. Hal ini diperkuat lagi oleh pendapat Hoyles (dalam Khiat, 2010: 1461) yang menyatakan bahwa beberapa siswa menganggap matematika sebagai subjek yang menimbulkan perasaan negatif seperti ketakutan, kecemasan, dan kekesalan selama pelajaran. Pemikiran siswa yang seperti ini menjadi salah satu penyebab siswa mengalami kendala dalam belajar matematika pada materi selanjutnya. Hal ini ditunjukkan dengan seringnya siswa melakukan kesalahan seperti salah konsep, salah prinsip, maupun 
kesalahan dalam perhitungan/komputasi. Hasil penelitian Jingga, dkk (2017:48) menyatakan bahwa kesalahan yang dilakukan semua kelompok siswa dalam belajar Trigonometri berupa strategi menjabarkan masing-masing hubungan perbandingan, kesalahan menuliskan tanda operasi matematika, kesalahan menuliskan tanda operasi matematika, dan kesalahan dalam melakukan operasi hitung bentuk aljabar sebagai akibat siswa tidak teliti saat melakukan perhitungan.

Secara umum berdasarkan beberapa pendapat tersebut terdapat tiga jenis kesalahan yang sering dilakukan oleh siswa yakni kesalahan konsep, kesalahan interpretasi bahasa, dan kesalahan dalam komputasi. Kesalahan konsep di antaranya dapat ditunjukkan dengan kesalahan siswa dalam memahami soal, baik mengenai apa yang diketahui dan ditanyakan dalam soal. Ketika siswa melakukan kesalahan konsep, hal ini dapat menyebabkan siswa tidak mampu menyelesaikan masalah pada tahap selanjutnya (Widodo, 2013). Muchlis (2017) menggolongkan jenis kesalahan yang dilakukan siswa pada setiap aspek penguasaan materi matematika menjadi 3 yakni kesalahan penggunaan konsep dalam materi, kesalahan operasi mengenai hubungan antara dua atau lebih objek matematika, dan kesalahan prinsip dalam melakukan perhitungan. Sedangkan Atim (2008) membedakan kesalahan dalam menyelesaikan soal matematika menjadi dua yaitu kesalahan konsep dan kesalahan bukan konsep yang satu contohnya adalah kesalahan dalam melakukan operasi perhitungan. Dalam penelitian ini jenis kesalahan siswa dibedakan menjadi tiga yakni kesalahan konsep, kesalahan prosedur, dan kesalahan komputasi.

Kereh, Subandar, \& Tjiang (2013:11) menyatakan bahwa kesulitan belajar matematika bisa terjadi pada hampir setiap jenjang pendidikan. Hasil penelitian Susanti dan Yulaida (2015) menunjukkan bahwa 80\% siswa mengalami kesulitan penguasaan konsep dan $80 \%$ siswa kesulitan dalam penguasaan prinsip. Adanya kesulitan-kesulitan siswa tersebut sering menyebabkan siswa membuat kesalahankesalahan dalam menyelesaikan suatu persoalan. Dengan demikian, kesalahankesalahan tersebut perlu diidentifikasi dan dianalisis, mengingat analisis kesalahan adalah studi mengenai kesalahan dalam hasil kerja siswa dengan tujuan untuk mencari penjelasan dalam kesalahan tersebut (Herholdt \& Sapire, 2014), agar dapat dicarikan solusinya sehingga siswa selanjutnya tidak mengulangi kesalahannya.

Dari sekian banyak faktor penyebab kesalahan siswa pada materi Trigonometri, kurangnya pemahaman siswa terhadap konsep matematika, kurang telitinya siswa dalam membaca soal, kesalahan perhitungan, dan kurang menariknya strategi kuis yang digunakan merupakan faktor strategis penyebab kesalahan yang dilakukan. Nuraeni \& Rosyid (2017) dan Hiltrimartin \& Pratiwi (2019) menyatakan bahwa sebaik apapun substansi materi ajar, tetapi jika penyampaiannya tidak dikemas secara baik, maka substansi tersebut tidak dapat sampai kepada siswa. Hal ini berarti kurang menariknya kegiatan pembelajaran yang dilaksanakan akan menyebabkan siswa bosan, kurang responsibilitas, dan kurang antusias dalam mengikuti pembelajaran.

Berdasarkan hal tersebut guru perlu memikirkan strategi yang dipilih agar pembelajaran menjadi lebih menarik, apalagi pada masa pandemi covid-19 di mana pembelajaran menggunakan sistem daring. Guru perlu usaha ekstra memikirkan strategi pemberian tugas atau kuis untuk siswanya. Berkaitan dengan pembelajaran sistem daring, maka guru juga perlu memikirkan strategi yang lebih baik ditempuh agar tugas atau kuis yang diberikan dapat membantu siswa dalam memahami materi dengan baik dan tidak terjadi salah konsep. Salah satu pilihan dari berbagai media kuis yang dapat digunakan dalam pembelajaran adalah media Kahoot. Penelitian mengenai penggunaan Kahoot oleh Wang (2015) menyatakan bahwa respon dari siswa saat dilaksanakannya kuis berbasis permainan mampu meningkatkan keterlibatan, motivasi, dan pembelajaran siswa setelah melaksanakannya berturut-turut.

688 BRILIANT: Jurnal Riset dan Konseptual

Volume 5 Nomor 4, November 2020 
Beberapa peneliti lain juga menyatakan bahwa pembelajaran menggunakan Kahoot mampu meningkatkan minat, aktivitas siswa, menjadikan siswa lebih fokus, meningkatkan kerjasama dan tanggung jawab, nyaman dalam belajar, dan meningkatkan atensi belajar siswa (Heni, dkk, 2019; Chaiyo \& Nokham, 2017).

Adapun tujuan dari tulisan ini adalah untuk mengidentifikasi kesalahan-kesalahan siswa dalam menyelesaikan soal-soal Trigonometri ditinjau dari strategi kuis yang digunakan dan mengidentifikasi faktor-faktor penyebab siswa melakukan kesalahan.

\section{METODE}

Penelitian ini merupakan penelitian deskriptif kualitatif untuk mengungkap, menganalisis, dan memberikan gambaran tentang jenis kesalahan dan faktor-faktor yang menyebabkan siswa membuat kesalahan-kesalahan dalam menyelesaikan soal Trigonometri. Adapun subjek pada penelitian ini adalah siswa kelas X MIPA 4 SMAN 1 Negara (pemberian kuis melalui Kahoot) dan kelas X MIPA 5 SMAN 1 Negara (pemberian kuis melalui WhatsApp), dengan banyak siswa masing-masing kelas adalah 36 orang. Dari ke dua kelas tersebut kemudian dipilih jawaban dari 2 orang siswa dari masing-masing kelas secara acak dengan mempertimbangkan kesalahan paling banyak yang dilakukan oleh siswa. Teknik pengumpulan data yang digunakan dalam penelitian ini adalah tes uraian dan wawancara. Tes ini digunakan untuk mengetahui prestasi belajar matematika siswa dan jenis kesalahan yang dilakukan oleh siswa tersebut. Tes yang digunakan memiliki reliabilitas sebesar 0,7741. Wawancara digunakan untuk mengetahui faktor-faktor penyebab siswa melakukan kesalahan dan dilakukan setelah menganalisis jawaban siswa.

Dalam penelitian ini teknik analisis data dilakukan melalui 3 langkah yakni reduksi data, penyajian data, dan penarikan kesimpulan. Untuk menguji keabsahan data digunakan triangulasi. Triangulasi adalah teknik validitas data yang memanfaatkan sesuatu yang lain di luar data itu untuk keperluan pengecekan atau sebagai pembanding terhadap data itu (Moleong, 2013). Triangulasi dalam penelitian ini dilakukan dengan membandingkan dan mengecek data tertulis jawaban siswa dengan hasil wawancara dengan siswa.

\section{HASIL}

Berikut disajikan kisi-kisi beserta soal dan jawaban siswa baik yang diberikan kuis melalui Kahoot maupun dengan WhatsApp.

1) Menentukan rasio trigonometri (sinus, cosinus, tangen, cosecant, secan, dan cotangen) pada segitiga siku-siku.

Soal: Perhatikan segitiga berikut.

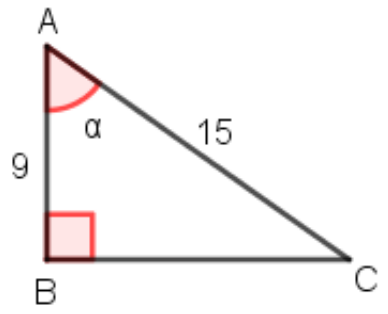

Jika $\angle A=\alpha$ maka tentukan nilai dari $\frac{\tan \alpha+\sec \alpha}{3 \csc \alpha+2 \tan \alpha}$ !

Deskripsi jawaban siswa untuk soal nomor 1

Semua siswa pada kelas yang diberikan kuis melalui Kahoot menjawab dengan benar, sedangkan pada kelas yang kuisnya melalu WhatsApp, ada 19 orang 
siswa memiliki kesalahan yang sama yakni kurang teliti dalam penghitungan (termasuk kesalahan operasi) seperti disajikan pada Gambar 1.

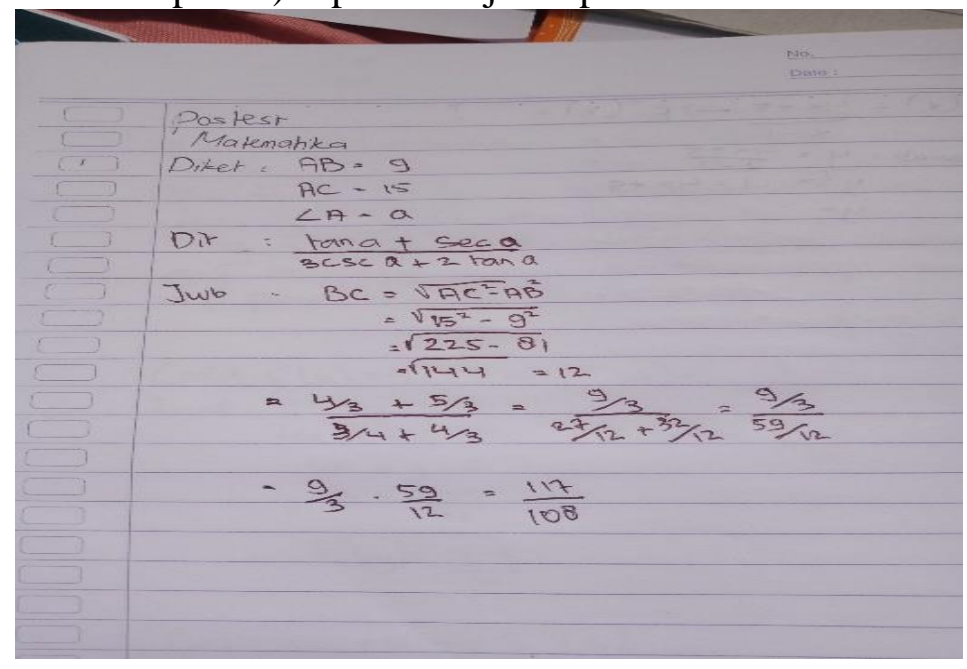

Gambar 1 Jawaban S1 kelompok WhatsApp.

2) Menyelesaikan masalah kontekstual yang berkaitan dengan rasio trigonometri pada segitiga siku-siku dan nilai rasio trigonometri sudut-sudut istimewa ( $\left.0^{\circ}, 30^{\circ}, 45^{\circ}, 60^{\circ}, 90^{\circ}\right)$.

Soal: Puncak mercusuar yang tingginya $12 \mathrm{~m}$ dapat dilihat dari sebuah kapal dengan sudut elevasi $30^{\circ}$. Tentukan jarak kapal dengan mercusuar tersebut!

Deskripsi jawaban siswa untuk soal nomor 2.

Pada kelas dengan Kahoot, ada 2 orang siswa yang belum memahami soal sehingga siswa kurang tepat dalam mengilustrasikan permasalahan (masih bingung dengan sudut elevasi dan sudut depresi). Kutipan pada Gambar 3 adalah salah satu jawaban siswa dari 2 siswa yang kesalahannya yang hampir sama.

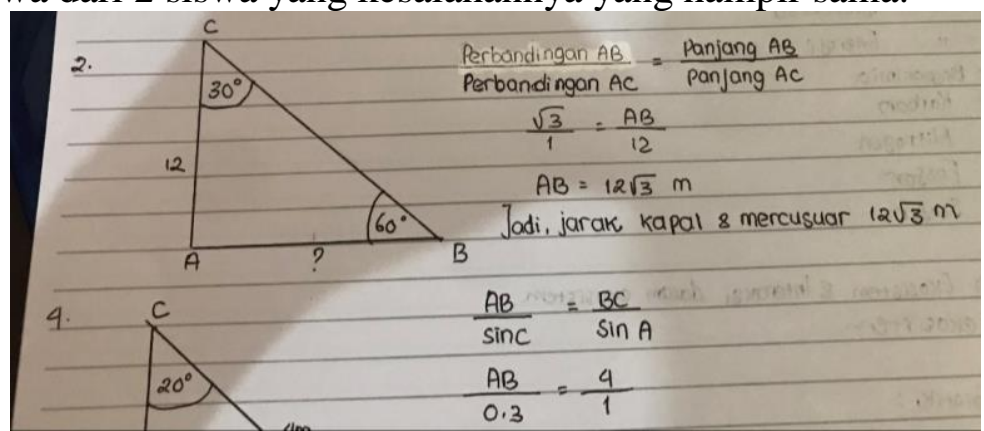

Gambar 2 Jawaban S1 kelompok Kahoot

Pada kelas yang kuisnya diberikan melalui WhatsApp, ada 11 orang siswa kurang teliti dalam perhitungan (kesalahan komputasi), seperti disajikan pada Gambar 3. 


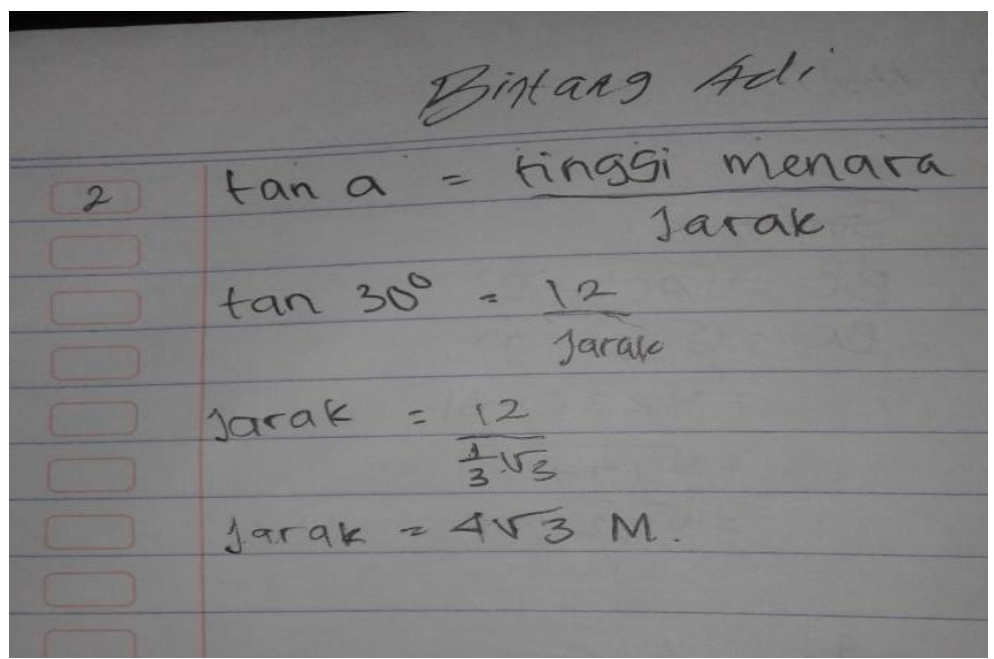

Gambar 3. Jawaban S2 kelompok WhatsApp

3) Menyelesaikan masalah kontekstual yang berkaitan dengan rasio trigonometri pada segitiga siku-siku dan nilai rasio trigonometri sudut-sudut istimewa ( $0^{\circ}, 30^{\circ}, 45^{\circ}, 60^{\circ}, 90^{\circ}$ ).

Soal: Andi berada di titik A dan berjarak $6 \sqrt{3} m$ dari titik B yang merupakan pangkal tiang bendera. Sudut elevasi di titik A terhadap puncak tiang bendera adalah $60^{\circ}$. Andi ingin memasang tali pada puncak tiang dengan cara merobohkan tiang bendera. Ia harus bergerak mundur menuju titik $\mathrm{C}$, sehingga jarak antara ujung tiang bendera yang dirobohkan ke titik $\mathrm{C}$ adalah $2 \mathrm{~m}$. Tentukan jarak Andi mundur ke titik $\mathrm{C}$ tersebut!

\section{Deskripsi Jawaban siswa pada soal nomor 3}

Untuk soal nomor 3, baik siswa kelas yang kuisnya dilakukan melalui Kahoot maupun siswa kelas yang kuisnya dilakukan melalui WhatsApp, memiliki permasalahan yang sama yakni siswa tidak memahami soal sehingga siswa terkecoh dalam mengilustrasikan permasalahan yang diberikan, akibatnya siswa melakukan kesalahan konsep dan prosedur, seperti disajikan pada Gambar 4 dan Gambar 5.

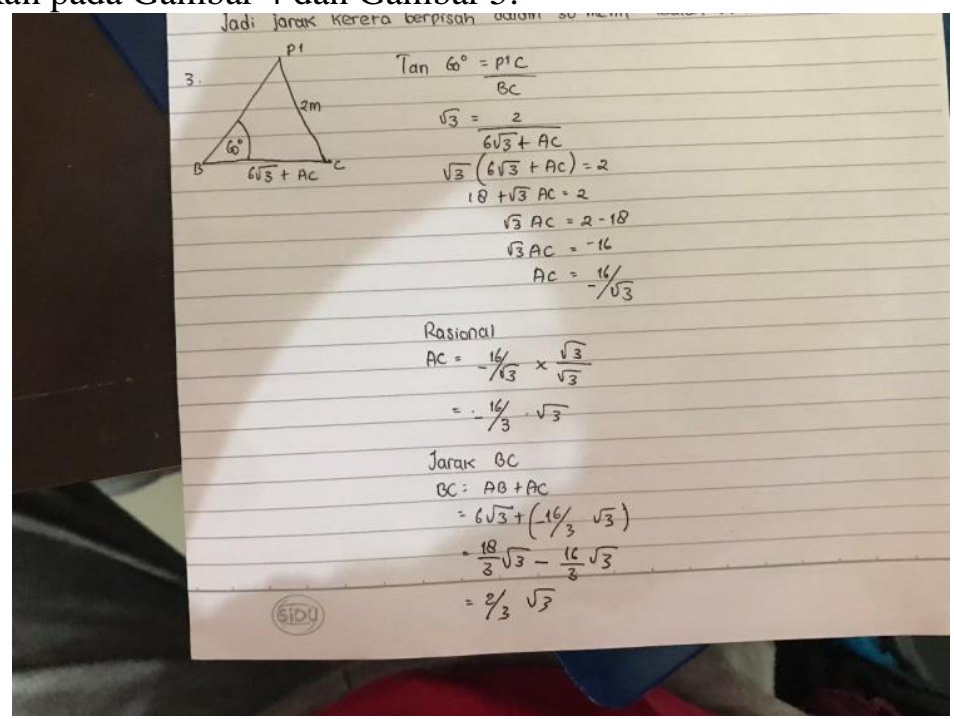

Gambar 4 Jawaban S1 kelompok Kahoot 


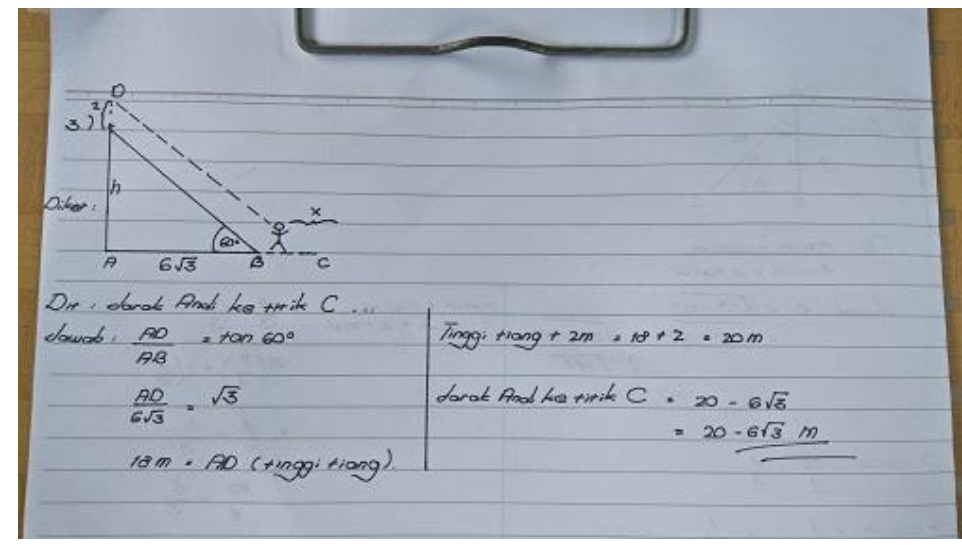

Gambar 5. Jawaban S2 kelompok WhatsApp

4) Menyelesaikan masalah kontekstual yang berkaitan dengan sudut-sudut berelasi Soal: Perhatikan gambar berikut.

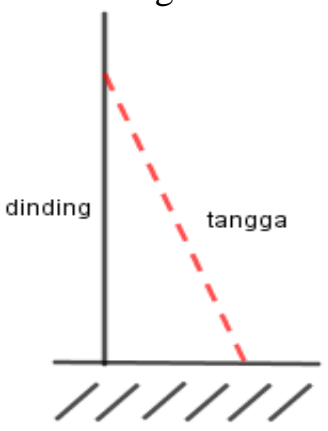

Sebuah tangga disandarkan pada dinding rumah. Besar sudut antara tangga dengan lantai adalah $70^{\circ}$ dan panjang tangga adalah $4 \mathrm{~m}$. Tentukan jarak ujung bawah tangga dengan dinding! $\left(\sin 20^{\circ}=0,3\right)$

\section{Deskripsi Jawaban siswa pada soal nomor 4}

Ada 1 orang siswa dari kelas yang kuisnya melalui WhatsApp tidak cermat dan belum lengkap dalam menjawab soal, seperti pada Gambar 6.

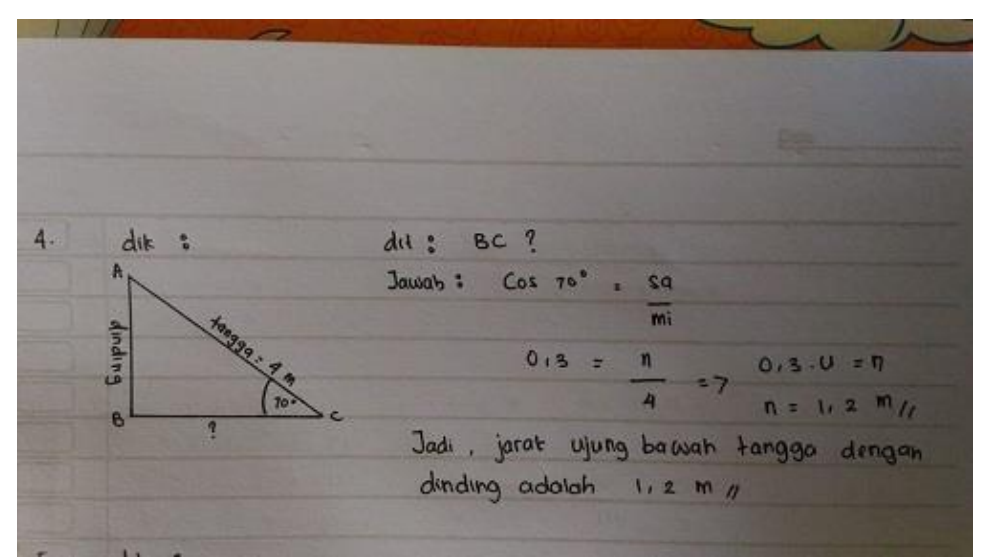

Gambar 6. Jawaban kurang lengkap dari S1 kelompok WhatsApp

5) Menyelesaikan masalah yang berkaitan dengan aturan sinus

Soal: Sebidang tanah berbentuk segitiga dan setiap titik sudutnya diberi tonggak pembatas A, B, dan C. Jika jarak antara tonggak A dan B adalah $300 m, \angle C A B$ adalah $75^{\circ}$, dan $\angle B C A$ adalah $60^{\circ}$. Tentukan jarak antara tonggak A dan $\mathrm{C}$ ! 


\section{Deskripsi Jawaban siswa pada soal nomor 5}

Baik siswa kelas yang kuisnya dilakukan melalui Kahoot maupun siswa kelas yang kuisnya dilakukan melalui WhatsApp melakukan kesalahan prosedur dan kesalahan komputasi. Pada Gambar 7 disajikan jawaban kelompok Kahoot.

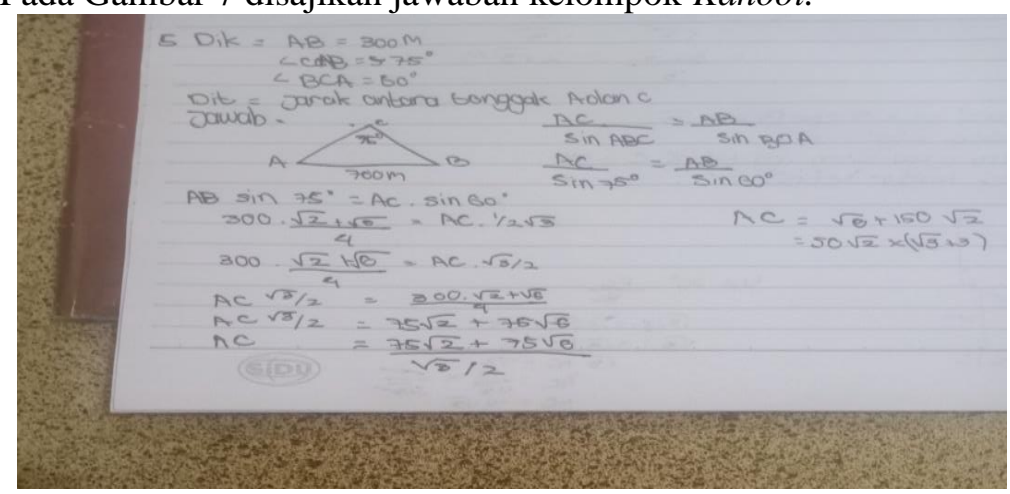

Gambar 7. Jawaban S3 kelompok Kahoot

6) Menyelesaikan masalah yang berkaitan dengan aturan cosinus

Soal: Dua kereta meninggalkan stasiun pada saat yang bersamaan. Kedua kereta tersebut bergerak sepanjang lintasan dengan sudut $60^{\circ}$. Jika salah satu kereta melaju dengan kecepatan rata-rata $100 \mathrm{~km} / \mathrm{jam}$ dan yang lainnya melaju dengan kecepatan rata-rata 90 $\mathrm{km} / \mathrm{jam}$. Tentukan jarak kereta berpisah dalam 30 menit (dalam km)!

\section{Deskripsi Jawaban siswa pada soal nomor 6}

Siswa pada dua kelompok memiliki permasalahan yang sama yakni belum mampu dalam menerjemahkan soal, sehingga siswa melakukan kesalahan prosedur dan kesalahan komputasi, seperti disajikan pada Gambar 8.

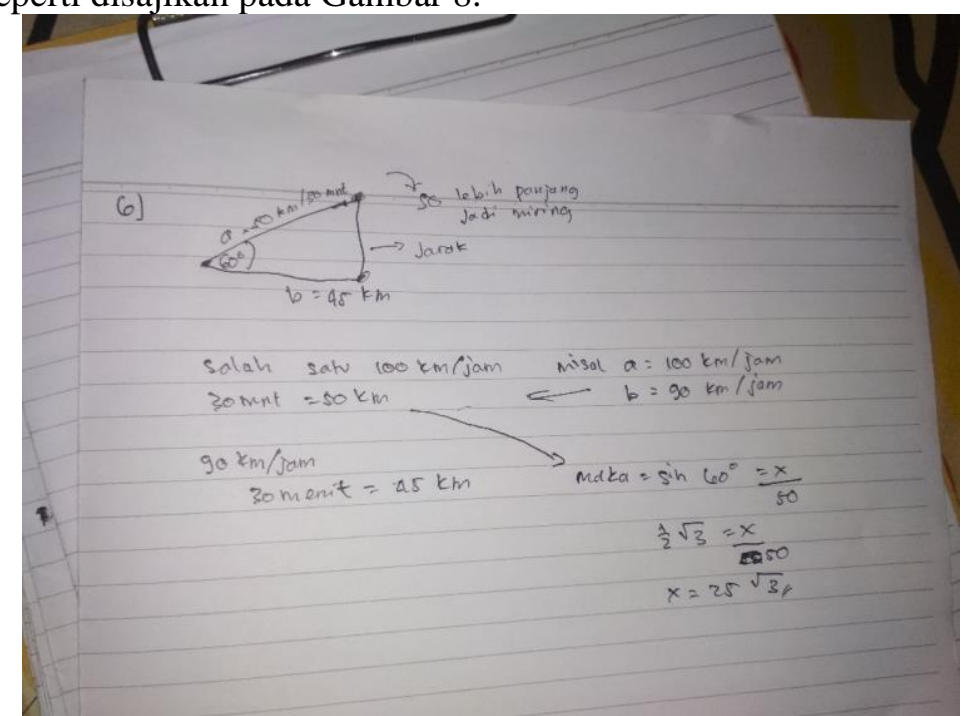

Gambar 8. Jawaban S3 kelompok WhatsApp

Berikut disajikan jenis dan banyaknya kesalahan antara siswa yang kuisnya melalui Kahoot dan siswa yang kuisnya melalui WhatsApp seperti disajikan pada Tabel 1 dan Tabel 2. 
Tabel 1 Banyak dan Jenis kesalahan Siswa Kelas Kahoot

\begin{tabular}{|l|c|c|c|c|c|c|}
\hline \multicolumn{1}{|c|}{ Keterangan } & Soal 1 & Soal 2 & Soal 3 & Soal 4 & Soal 5 & Soal 6 \\
\hline $\begin{array}{l}\text { Banyak siswa salah } \\
\text { komputasi }\end{array}$ & 0 & 5 & 6 & 7 & 11 & 8 \\
\hline $\begin{array}{l}\text { Banyak siswa yang salah } \\
\text { prosedur }\end{array}$ & 0 & 0 & 0 & 0 & 1 & 18 \\
\hline $\begin{array}{l}\text { Banyak siswa salah } \\
\text { konsep }\end{array}$ & 0 & 2 & 24 & 1 & 0 & 2 \\
\hline $\begin{array}{l}\text { Persentase siswa } \\
\text { menjawab benar }\end{array}$ & $100 \%$ & $81 \%$ & $17 \%$ & $78 \%$ & $67 \%$ & $22 \%$ \\
\hline $\begin{array}{l}\text { Persentase siswa } \\
\text { menjawab salah }\end{array}$ & $0 \%$ & $19 \%$ & $83 \%$ & $22 \%$ & $33 \%$ & $78 \%$ \\
\hline
\end{tabular}

Tabel 2 Banyak dan Jenis kesalahan Siswa Kelas WhatsApp

\begin{tabular}{|l|c|c|c|c|c|c|}
\hline \multicolumn{1}{|c|}{ Keterangan } & Soal 1 & Soal 2 & Soal 3 & Soal 4 & Soal 5 & Soal 6 \\
\hline $\begin{array}{l}\text { Banyak siswa yang } \\
\text { salah komputasi }\end{array}$ & 19 & 11 & 6 & 12 & 16 & 6 \\
\hline $\begin{array}{l}\text { Banyak siswa yang } \\
\text { salah prosedur }\end{array}$ & 4 & 3 & 11 & 3 & 1 & 24 \\
\hline $\begin{array}{l}\text { Banyak siswa salah } \\
\text { konsep }\end{array}$ & 0 & 0 & 16 & 0 & 0 & 3 \\
\hline $\begin{array}{l}\text { Persentase siswa } \\
\text { menjawab benar }\end{array}$ & $36 \%$ & $61 \%$ & $8 \%$ & $58 \%$ & $53 \%$ & $8 \%$ \\
\hline $\begin{array}{l}\text { Persentase siswa } \\
\text { menjawab salah }\end{array}$ & $64 \%$ & $39 \%$ & $92 \%$ & $42 \%$ & $47 \%$ & $92 \%$ \\
\hline
\end{tabular}

Berdasarkah hasil yang telah disajikan baik pada deskripsi jawaban siswa maupun pada Tabel 1 dan Tabel 2, maka jenis kesalahan yang sering dilakukan siswa kelas X MIPA 4 dan kelas X MIPA 5 SMAN 1 Negara adalah kesalahan konsep, kesalahan prosedur, dan kesalahan komputasi. Adapun persentase kesalahan siswa kelas X MIPA 4 SMAN 1 Negara pada masing-masing soal adalah sebagai berikut. Untuk soal nomor 2 ada sebesar 13,89\% siswa melakukan kesalahan komputasi, sebesar 5,56\% siswa melakukan kesalahan konsep. Untuk soal nomor 3 siswa yang melakukan kesalahan komputasi sebesar 16.7\%, dan yang melakukan kesalahan konsep sebesar $66,67 \%$. Untuk soal nomor 4 sebanyak $19.44 \%$ siswa melakukan kesalahan komputasi dan sebanyak 2,78\% siswa melakukan kesalahan konsep. Untuk soal nomor 5 ada sebesar 30,56\% siswa membuat kesalahan komputasi dan 9,22\% melakukan kesalahan konsep., sedangkan untuk soal nomor 6 ada sebesar 22,22\% siswa melakukan kesalahan komputasi, sebesar 50\% siswa membuat kesalahan prosedur dan sebesar 5,56\% melakukan kesalahan konsep. Sedangkan untuk siswa kelas X MIPA 5 SMAN 1 Negara yang kuisnya melalui WhatsApp, persentase kesalahan siswa pada masing-masing soal adalah sebagai berikut. Untuk soal nomor 1 ada sebesar 52,72\% siswa melakukan kesalahan komputasi, 11,11\% melakukan kesalahan prosedur. Untuk soal nomor 2 ada sebesar $61,11 \%$ melakukan kesalahan komputasi, sebesar 3,06\% melakukan kesalahan prosedur. Untuk soal nomor 3 siswa yang melakukan kesalahan komputasi sebesar $16,7 \%$, dan siswa yang melakukan kesalahan prosedur $30,56 \%$ dan sebesar 44,44\% siswa melakukan kesalahan konsep. Untuk soal nomor 4 sebanyak 33,33\% siswa melakukan kesalahan komputasi dan sebanyak 8,33\% siswa melakukan kesalahan prosedur. Untuk soal nomor 5 ada sebesar $44,44 \%$ siswa membuat kesalahan komputasi dan 2,78\% melakukan kesalahan prosedur. Untuk soal nomor 6 ada

694 BRILIANT: Jurnal Riset dan Konseptual Volume 5 Nomor 4, November 2020 
sebesar 16,70\% siswa melakukan kesalahan komputasi, sebesar 66,67 \% melakukan kesalahan prosedur dan $8,83 \%$ melakukan kesalahan konsep.

\section{PEMBAHASAN}

Pelaksanaan kuis menggunakan Kahoot memiliki sisi yang menarik yaitu saat siswa telah menjawab soal, langsung ditampilkan jawaban yang benar, jawaban salah, dan skor tiap-tiap peserta sehingga siswa dapat mengetahui salah atau benar jawaban yang diberikan dan berkompetisi dalam menjawab pertanyaan berikutnya. Setiap soal juga memiliki waktu menjawab yang dapat disetting oleh pendidik (maksimal 4 menit). Semakin cepat dan tepat jawaban yang dipilih siswa maka skor yang diperoleh semakin tinggi. Siswa juga mendapatkan skor tambahan apabila menjawab soal benar secara berturut-turut. Dengan demikian siswa menjadi lebih tertantang untuk mendapatkan skor tertinggi dan mencapai podium teratas.

Hal yang diperhatikan dalam menjawab soal kuis menggunakan Kahoot ini adalah ketepatan memilih jawaban dan kecepatan dalam menjawab soal. Siswa yang menjawab dengan benar dan cepat tentu memperoleh skor yang lebih tinggi dari siswa yang menjawab dengan benar namun lambat. Sedangkan siswa yang menjawab salah tidak mendapatkan skor. Waktu dalam pengerjaan soal ini dapat diatur oleh guru sebagai pembuat kuis. Guru harus dapat memprediksi apakah soal yang diberikan memerlukan durasi singkat atau lama. Durasi tersingkat dalam pengerjaan soal yaitu 20 detik dan durasi terlamanya yaitu 240 detik. Jika siswa menjawab pertanyaan dengan benar secara berturut-turut, maka siswa mendapatkan skor tambahan. Sehingga kekonsistenan dalam menjawab soal dengan benar juga menjadi faktor dalam penilaian (Kirana, 2020).

Sedangkan saat pengamatan selama proses penelitian dengan memberikan kuis melalui WhatsApp, kurang berhasil menekankan keaktifan siswa dalam proses pembelajaran karena masih didominasi oleh siswa-siswa yang pandai. Di akhir pembelajaran guru mengirimkan beberapa soal kuis ke grup WhatsApp kelas dan menetapkan durasi pengerjaan kuis kepada siswa, tetapi antusiasme siswa untuk mengerjakan kuis tersebut juga masih mengandalkan siswa yang dominan di kelas dan greget siswa untuk menunjukkan hasil yang maksimal juga belum tercapai. Secara umum berdasarkan pengamatan peneliti pada saat pembelajaran berlangsung menunjukkan bahwa siswa yang kuisnya melalui Kahoot lebih aktif dalam menggali pengetahuannya, lebih kompetitif, serta memiliki percaya diri dalam menjawab soal dibandingkan dengan siswa yang kuisnya melalui WhatsApp. Hasil penelitian ini sejalan penelitian yang dilakukan oleh (Irwan, 2019) yang menunjukkan bahwa penggunaan media Kahoot mampu meningkatkan hasil belajar siswa. Pelaksanaan kuis melalui Kahoot dalam proses pembelajaran dapat meningkatkan fokus siswa dalam menjawab soal kuis sehingga mampu meningkatkan prestasi belajar matematika. Penggunaan Kahoot juga menjadikan siswa lebih berkonsentrasi dan nyaman dalam belajar, serta motivasi belajar yang meningkat (Chaiyo \& Nokham, 2017). Inovasi dalam media belajar yang interaktif dapat membangun minat belajar siswa, selain itu siswa lebih semangat dalam belajar karena tampilan pada media belajar yang pada akhirnya peningkatan prestasi belajar siswa pun terjadi. Hal-hal tersebut merupakan salah satu faktor yang menyebabkan persentase siswa yang membuat kesalahan pada kelas Kahoot lebih rendah daripada persentase siswa pada kelas WhatsApp. Hal ini dapat terjadi mengingat kelebihan yang dimiliki media Kahoot seperti yang diungkapkan (Subiyantoro \& Mulyani, 2017) bahwa pemberian kuis melalui Kahoot membuat siswa mampu mengetahui tingkat pemahamannya sendiri dan interaktivitas dari kuis yang disajikan menjadikan siswa 
lebih fokus. Penilaian dengan menggunakan media pembelajaran menjadi perpaduan inovatif di kelas online karena memberikan banyak manfaat (Winger \& Miller, 2018)

\section{KESIMPULAN}

Berdasarkan hasil analisis data yang telah peneliti lakukan, maka dapat disimpulkan: (1) Persentase kesalahan (komputasi, prosedur dan konsep) yang dilakukan siswa kelas X MIPA 4 (yang pemberian kuisnya melalui Kahoot) lebih rendah daripada siswa kelas X MIPA 5 (yang pemberian kuisnya melalui WhatsApp), (2) faktor- faktor yang menyebabkan siswa melakukan kesalahan dalam mengerjakan soal Trigonometri antara lain: (a) Siswa kurang mampu memahami materi Trigonometri yang telah diajarkan oleh guru. (b) Siswa terburu-buru dalam mengerjakan soal sehingga siswa kurang ketelitiannya dalam mengerjakan soal, (c). siswa terbiasa tidak membuat jawaban lengkap karena sering tidak disalahkan guru, jika jawabannya benar, d) strategi kuis juga turut andil menyebabkan siswa melakukan banyak kesalahan saat mengerjakan soal Trigonometri karena siswa tidak dapat berdiskusi secara langsung dan mereka merasa kurang bebas bertanya dengan teman ataupun gurunya.

\section{SARAN}

Berdasarkan hasil penelitian, maka penulis menyarankan kepada pembaca atau guru yang berminat menggunakan Kahoot maupun WhatsApp (meskipun dalam penelitian ini penggunaan Kahoot memberikan hasil yang lebih unggul daripada melalui WhatsApp) dalam memberikan kuis dalam proses pembelajarannya agar memperhatikan kendala yang terjadi seperti sinyal dan juga harus memastikan jika semua siswa sudah bergabung dan siap dalam pelaksanaan kuis serta mengingatkan siswa agar mengerjakan kuis secara individu. Di samping itu, guru diharapkan selalu merancang strategi dan waktu agar ada kesempatan untuk membahas kesalahan yang dilakukan siswa setiap memberikan kuis maupun tugas lainnya, sehingga kesalahan tersebut segera dapat diantisipasi dan tidak terulang. Bagi peneliti yang tertarik untuk menganalisis kesalahan pekerjaan siswa mungkin bisa dilanjutkan untuk topik lainnya dengan subyek yang lebih banyak.

\section{DAFTAR RUJUKAN}

Bahruddin, A. 2007. Pendidikan Alternatif Qaryah Thayyibah. Yogyakarta: LKIS. Baharuddin \& Makin, M. 2007. Pendidikan Humanistik (Konsep, Teori dan Aplikasi Praksis dalam Dunia Pendidikan). Yogjakarta: Ar-Ruzz Media.

Bauer, T., Kniffin, L. E., \& Priest, K. L. (2015). The Future of Service-Learning and Community Engagement: Asset-Based Approaches and Student Learning in First-Year Courses Service-Learning in a First-Year Course. Michigan Journal of Community Service Learning, 22(1), 89-92. Retrieved from https://files.eric.ed.gov/fulltext/EJ1137421.pdf

Combs, P. H. \& Ahmed, M. 1985. Memerangi Kemiskinan di Pedesaan Melalui Pendidikan Non-Formal. Jakarta: Rajawali.

Eyler, J. S., Giles, D. E., Stenson, C. M., \& Gray, C. J. (2001). At A Glance: What We Know About The Effects of Service Learning on Student, Faculty, Institutions, and Communities, 1993-2000: Third Edition. Nashville, TN: Vanderbilt University Press.

Ferguson, A. (2006). Making the Case for Service-Learning in First-Year Programs. The Vermont Connection, 27.

Galbraith, M. W. (1995). Community-Based Organizations And The Delivery Of

696 BRILIANT: Jurnal Riset dan Konseptual

Volume 5 Nomor 4, November 2020 
Lifelong Learning Opportunities.

Keraf, A. S. (2014). Filsafat lingkungan hidup, alam sebagai sebuah sistem kehidupan. Yogyakarta: Kanisius

Ma'arif, S., Kholiq, A., \& Elizabeth, M.Z. 2012. School Culture di Madrasah dan Sekolah. Semarang: IAIN Walisongo Semarang.

McBeth, W. \& Volk, T.L. (2010). The national environmental literacy project: a baseline study of middle grade students in the United States. The Journal of Environmental Education, 41(1)

Melaville, A., Berg, A. C., \& Blank, M. J. (2006). Community Based Learning Engaging Students for Succes and Citizenship. https://doi.org/10.1002/TRTR.01099

National Research Council. (2009). A New Biology for the 21st Century. In A New Biology for the 21st Century. Washington, DC: The National Academies Press. https://doi.org/10.17226/12764

Perrotti, C. (2019). Review Essay: The Campus and the Neighborly Community. Michigan Journal of Community Service Learning, 25(2). https://doi.org/10.3998/mjcsloa.3239521.0025.205

Rosyada, D. (2007). Paradigma Pendidikan Demokratis: Sebuah Model Pelibatan Masyarakat dalam Penyelenggaraan Pendidikan. Jakarta: Kencana Perdana Media.

Rusmawan. (2017). Ecoliteracy Dalam Konteks Pendidikan Ips. Jurnal Sosio Didaktika: Social Science Education Journal, 4 (2)

Wickersham, C., Westerberg, C., Jones, K., \& Cress, M. (2016). Pivot Points: Direct Measures of the Content and Process of Community-based Learning. Teaching Sociology, 44(1), 17-27. https://doi.org/10.1177/0092055X15613786

Zlotkowski, E. (1995). Does Service Learning Have a Future? Michigan Journal of Community Service Learning. 2(1), 123-133.

Undang-Undang Republik Indonesia Nomer 20 Tahun 2003 Tentang Sistem Pendidikan Nasional. http://kemenag.go.id/file/dokumen/UU2003.pdf 